\title{
ГЛОБОЛОКАЛЬНИЙ ВИМІР В КОНЦЕПЦІЇ СТАЛОГО РОЗВИТКУ
}

\author{
О. Г. Конончук \\ Рівненський державний гуманітарний університет, \\ вул. Пластова 31, каб. 229, 33028, \\ Alexander.Kononchuk.USA@gmail.com
}

\begin{abstract}
У статті розглянуто глоболокальний вимір в концепції сталого розвитку суспільства та наведено компаративний аналіз сталого розвитку регіонів світу й окремих держав, здійснено крос-темпоральне порівняння від глобального до локальних рівнів. Автор наводить хронологічну послідовність формування концепції сталого розвитку суспільства, в якій основну роль відіграла Організація Об'єднаних Націй і низка постанов та декларацій, прийнятих Генеральною Асамблеєю, починаючи з другої половини XX ст. У роботі представлена еволюція концепції сталого розвитку від суто екологічних та економічних трактувань до тлумачення сталого розвитку як комплексної системи, яка охоплює екологічний, економічний та соціальний індикатори. Також у статті наведені трактування категорії сталого розвитку як закордонних, таквїтчизняних науковців.

Особливу увагу автор зосереджує на індексах та індикаторах сталого розвитку суспільства, що дає змогу виміряти рівень сталості суспільства (суспільств) від глобального до локального рівнів. Для проведення глоболокального вимірювання сталого розвитку автор використовує два індекси - «Індекс сталості суспільства» (The Sustainable Society Index) та «Індекс сталого розвитку» (Sustainable Development Index) регіонів України. За допомогою першого індексу здійснюється вимірювання сталості суспільства на глобальному, регіональному (за регіонами світу) та національному рівнях, представлений рейтинг країн та регіонів світу, а також динаміка змін сталості суспільства на різних рівнях протягом десятирічного періоду. Другий індекс використовується для дослідження сталого розвитку регіонів України та наводиться рейтинг адміністративно-територіальних одиниць вищого рівня.

Ключові слова: сталий розвиток, концепція сталого розвитку суспільства, Організація Об'єднаних Націй $(\mathrm{OOH})$, індикатор сталого розвитку, індекс сталого розвитку, «Індекс сталості суспільства» (Sustainable Society Index), «Індекс сталого розвитку» (Sustainable Development Index).
\end{abstract}

Проблематика дослідження та аналіз останніх джерел і публікацій. У рамках діяльності міжнародних структур та організацій, зокрема ООН, укладено низку міжнародних договорів, постанов і декларацій, спрямованих на вирішення проблем сталого розвитку суспільства. Найбільш важливе значення мають наступні міжнародні договори: Декларація Конференції ООН з проблем довкілля (Стокгольм, 1972 р.); Доповідь Всесвітньої комісії з питань довкілля і розвитку (Нью-Йорк, 1987 р.); Декларація з довкілля і розвитку (Ріо-де-Жанейро, 1992 р.); Декларація тисячоліття ООН

(C) Конончук О. Г., 2017 
(Нью-Йорк, 2000 р.); Йоганнесбурзька декларація зі сталого розвитку (Йоганнесбург, 2002 р.); Резолюція ГА ООН «Перетворення нашого світу: порядок денний в області сталого розвитку на період до 2030 року» (Нью-Йорк, 2015 р.) та низка менш значущих договорів і декларацій, прийнятих починаючи з 1968 р. і понині.

Науково-практичне значення мають публікації таких закордонних та вітчизняних авторів, як Донелла Медоуз, Денніс Медоуз, Гру Гарлем Брундтланд, Йорген Рандерс, Вільям Бернс, М. Стронгон, Г. Кларк, Х. Босель, К. Снеддон, Р. А. Перелет, Б. Е. Большаков, С. А. Рябкова, А. Садовенко, М. М. Моїсеєв, А. Д. Урсул, В. Оленєв, М. З. Згуровський, А. Д. Гвішіані, В. І. Куценко, Р. В. Войтович та інші.

Формування концепції сталого розвитку. Передумови формування концепції сталого розвитку беруть свій початок з кінця 1960-х рр. У цей час відбувається відхід від трактування поняття «розвиток» тільки як економічного зростання. Розширення цієї ідеї відбувається внаслідок насамперед соціальної проблематики. Протягом кінця XX початку XXI ст. Організацією Об'єднаних Націй був зроблений значний внесок у розробку та впровадження в практику концепції сталого розвитку суспільства (див. табл. 1).

Концептуально поняття сталого розвитку було сформовано Міжнародною комісією $з$ довкілля та розвитку (МКДР) на чолі з прем’єр-міністром Норвегії Гру Гарлем Брундтланд у 1987 р. «Сталий розвиток - це такий розвиток, який задовольняє потреби теперішнього часу, але не ставить під загрозу можливості майбутніх поколінь задовольняти свої особисті потреби», - зазначається в доповіді [16].

Міжнародний інститут сталого розвитку (IISD), заснований у 1990 р., (Вінніпег, Канада), у такий спосіб визначає обговорюваний термін: «Сталий розвиток означає об’єднання єдиного довкілля, економічної ефективності та добробуту народів».

ОН в Ріо-де-Жанейро відразу ж після іії проведення на чолі з головою Морісом Стронгом, генеральним секретарем цієї конференції, дає наступну формулу Ради Землі: «Стійкість - проста концепція: жити по справедливості в рамках наших екологічних можливостей». У змісті терміна виділені два імперативи: імператив екологічної стійкості та імператив соціально-економічної стійкості. Імператив екологічної стійкості жити в рамках наших можливостей: вимоги людства до природи перевершують іiї можливості, людство повинно зменшити споживання природних ресурсів, скорочуючи своє споживання і виробництво відходів. Імператив соціально-економічної стійкості - жити по справедливості: послаблювати руйнівні конфлікти між поколіннями, породжені величезною соціальною й економічною нерівністю; жити з економічних засобів [12].

Ідеї сталого розвитку знаходять втілення в політиці багатьох країн світу. У Норвегії була підготовлена доповідь парламенту за рішеннями КДР і їх наслідків для країни. У Швеції був прийнятий закон про виконання рішень КДР. Великобританія і США розробили стратегії сталого розвитку (1994 та 1996 року відповідно). Закон про сталий розвиток ухвалено в Естонії. У Нідерландах був прийнятий «План дій - стійкі Нідерланди» (1992 р.), у Канаді - «Програма дій для суспільства», в Австралії - «Національна стратегія екологічно сталого розвитку» (1992 p). П'ята екологічна програма Європейського Союзу була названа «Стратегія на шляху до стійкості». У 1997 р. прийнята «Стратегія сталого розвитку Білорусі». Екологічні фактори були включені в макроекономічні стратегії низки країн, таких, як Коста-Ріка і Гамбія, Китай, Танзанія та інші. В ряді країн почали розробляти локальні порядки денні на XXI століття [3, с. 94-95]. 


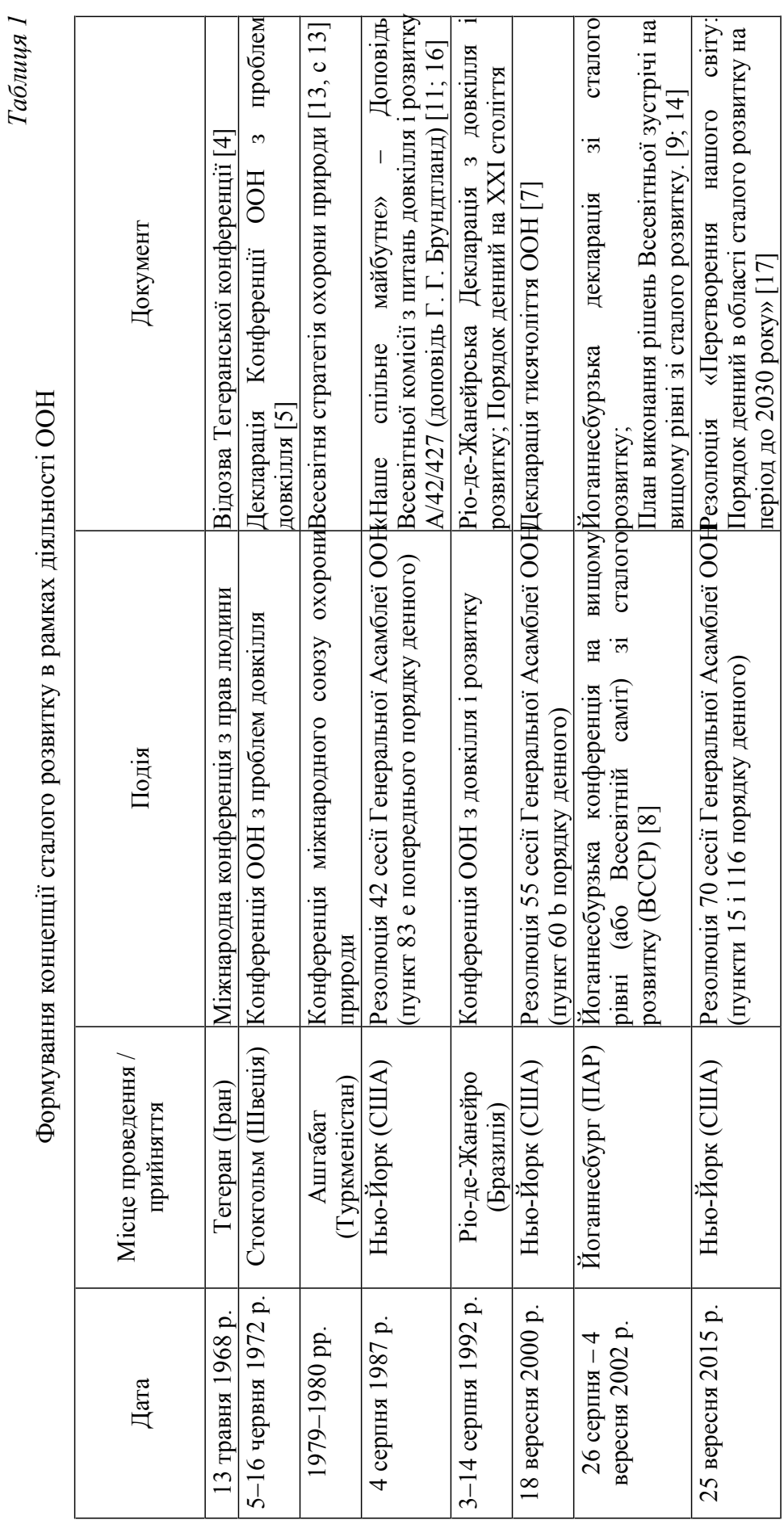


Рада Землі (Сан-Хосе, Коста-Ріка), створена для реалізації рішень Конференції ОСьогодні існує багато суперечностей в трактуванні поняття «сталий розвиток», особливо актуально це проявляється в українських та російських наукових колах, де існує проблема з правильністю перекладу самого поняття. Словосполучення «сталий розвиток» $€$ перекладом з англійської мови: «sustainable development» дослівно означає «розвиток, що підтримується» (sustain - опора, підтримувати, витримувати). Російською мовою перекладається як «устойчивое развитие».

Деякі фахівці вважають, що більш вдалим перекладом українською мовою було б словосполучення «стійкий розвиток», бо «сталий», «усталений» означає скоріше «стабільний», «постійний», тобто здатний не змінюватися або підтримувати певні (стабільні) темпи руху, поступу, розвитку (російською - установившийся). Але саме явище, про яке йдеться, містить у собі ще один аспект - здатність утримувати рівновагу, не падати, не руйнуватися, і він, цей аспект, більш адекватно характеризується словосполученням «стійкий розвиток» [19].

Подібні проблеми з перекладом поняття сталого розвитку є також і в російській мові, що в свою чергу викликає чимало критичних зауважень. Про це писав ще М. М. Моїсеєв, відзначаючи, що «переклад терміна «sustainable development» $€$ деяким лінгвістичним нонсенсом, бо сталого розвитку просто не може бути - якщо $є$ розвиток, то стабільності вже немає», i давав визначення «sustainable development» як «розвитку, допустимого або узгодженого зі станом природи і їі законами» [10]. Потрібно зазначити, що переклад поняття «sustainable development» як на українську («сталий розвиток»), так і на російську мову («устойчивое развитие») має подібне значення, тому розглядати український та російський варіанти перекладу можна як єдину категорію.

М. Моїсеєв додає, що «сталий розвиток слід інтерпретувати як стратегію перехідного періоду до такого стану природи й суспільства, яке можна схарактеризувати терміном «коеволюція», або «епоха ноосфери». Прщьому збереження біосфери - умова необхідна, але недостатня» [10].

А. Урсул і А. Романович дають наступне визначення сталого розвитку: сталий розвиток - це: 1) розвиток людства, при якому задоволення потреб теперішніх поколінь здійснюється без шкоди для майбутніх поколінь; 2) керований збалансований розвиток суспільства, що не руйнує своєї природної основи та забезпечує безперервний прогрес цивілізації. Поява нової стратегії розвитку означає поступове з'єднання в єдину самоорганізовану систему економічної, екологічної та соціальної сфер діяльності. У цьому сенсі сталий розвиток має характеризуватися економічною ефективністю, біосферною сумісністю і соціальною справедливістю при загальному зниженні антропогенного тиску на біосферу [21].

Б. Большаков зазначає: «Сталий розвиток країни (суспільства) - це хронологічно цілісний процес збереження неспадаючих темпів зростання виробленої країною корисної потужності при незбільшенні темпів споживаної країною потужності, скорочення потужності внаслідок відтворюваних проривних технологій і підвищення якості управління на всіх рівнях: світ в цілому, країна, суб’єкти (регіони країни), галузі, муніципалітети, підприємства, людина» [2, с. 78].

Індекси та індикатори сталого розвитку суспільства. Важливою проблемою на шляху втілення концепції сталого розвитку є формування системи вимірювання для 
кількісного та якісного оцінювання цього дуже складного процесу. Головними вимогами до зазначеної системи є іiі інформаційна повнота та адекватність представлення взаємопов'язаної тріади складових сталого розвитку. В цьому напрямі зараз працюють як відомі міжнародні організації, так і численні наукові колективи, але ії однозначного узгодження поки що не досягнуто.

Згідно з МВСР - Метрикою вимірювання сталого розвитку (Sustainable Development Gauging Matrix, SDGM), - сталий розвиток оцінюється за допомогою відповідного індексу в просторі трьох вимірів: економічного, екологічного та соціального + інституціонального. Цей індекс є вектором, норма якого визначає рівень сталого розвитку. Одним з важливих застосувань МВСР є використання фактичних даних про індикатори та параметри сталого розвитку для конкретногфегіону з метою прийняття цілеспрямованих рішень на різних рівнях керування.

Індикатор сталого розвитку - це кількісне представлення певної характеристики одного або більше вимірів розвитку, яке дозволяє оцінювати прогрес, підвищувати ефективність і дієвість прийняття рішень за допомогою спрощення й агрегування великих обсягів інформації й надання іiї у вигляді такої «згортки» особам, щøриймають рішення.

Якщо індикатори деяким чином агреговані, результуючий показник називають індексом. Індекс сталого розвитку - це інтегрована оцінка, яка враховує сумісно усі три виміри сталого розвитку, і тим самим відображає взаємозв'язок між трьома нероздільними сферами розвитку суспільства - економічною, екологічною та соціальною $[20$, с. 6,14$]$.

Світовою спільнотою активно розробляються і вже впроваджеңдекілька варіантів оцінки показників сталого розвитку, серед яких найбільш відомими $є$ «Індекс людського розвитку», «Індекс глобальної конкурентоспроможності», «Індекс економічної свободи», «Індекс екологічної сталості» та «Індекс якості життя».

«Індекс людського розвитку» (Human Development Index) розроблений Програмою розвитку ООН. Три елементи індексу відображають довге і здорове життя, знання й належний рівень життя, а показники - очікувану тривалість життя, рівень грамотності дорослого населення, сукупну загальну частку осіб, що навчаються, й ВВП на душу населення [32].

«Індекс глобальної конкурентоспроможності», або «Індекс конкурентоспроможного розвитку» (Global Competitiveness Index, GCI), розроблений організаторами Всесвітнього економічного форуму. Індекс формується на основі трьох груп комплексних індикаторів: індикаторів базових вимог, індикаторів підвищення ефективності, індикаторів інноваційності [31].

«Індекс економічної свободи» (Index of Economic Freedom) розроблений інтелектуальним центром фундації «Heritage Foundation». Індекс формується на основі індикаторів рівня свободи бізнесу, свободи торгівлі, фіскальної свободи, залежності економіки від уряду, монетарної свободи, інвестиційної свободи, фінансової свободи, свободи від корупції, свободи ринку праці та прав на приватну власність. Індикатори обчислюються на основі експертного оцінювання та використання різноманітнихних економічного, фінансового, законодавчого та адміністративного характеру [22]. 
«Індекс екологічної сталості» (Environment Sustainability Index, ESI) кількісно визначає ймовірність, з якою країна буде здатна зберігати наявні ресурси навколишнього природного середовища протягом наступних десятиліть, та оцінює потенціал країни щодо запобігання екологічній деградації. Індекс побудований за схемою «змінна (76) індикатор (21) - компонент (5) - індекс» [23].

«Індекс якості життя» (The Quality of Life Index) - комбінований показник, який вимірює досягнення країн світу й окремих регіонів з точки зору їх здатності забезпечити своїм жителям щасливе життя. Розрахований за методикою британського дослідницького центру «The Economist Intelligence Unit» (аналітичний підрозділ британського журналу «Economist»), заснованій на комбінації статистичних даних і результатів опитувань громадської думки з відповідних країн. «Індекс якості життя» вимірює результати суб'єктивної задоволеності життям громадян різних країн світу і співвідносить їх з об'єктивними показниками соціально-економічного добробуту жителів цих країн. Індекс складається на основі статистичного аналізу дев'яти ключових показників, які відображають різні аспекти якості життя населення: здоров'я, сімейне життя, громадське життя, матеріальний добробут, політична стабільність і безпека, клімат і географія, рівень зайнятості, політичні та громадянські свободи, гендерна рівність [30].

На думку автора, всі вищеперераховані індекси хоча й орієнтовані на дослідження сталого розвитку суспільства, проте не мають комплексного характеру в дослідженні всіх трьох компонентів сталого розвитку: економічного, соціального та екологічного. Особливу увагу автор приділяє «Індексу сталості суспільства» (The Sustainable Society Index), який синтезує такі елементи, як добробут людини, економічний та екологічний добробут, які відповідають трьом принципам сталого розвитку.

«Індекс сталості суспільства» був розроблений з ініціативи нідерландських дослідників Герта ван де Керка та Артура Мануеля під егідою Фонду сталого суспільства в 2006 р. До редакційної ради видання індексу входять представники низки дослідницьких центрів і незалежні міжнародні експерти, які використовують у своїй роботі аналітичні розробки та статистичні дані міжнародних організацій. Аудит, структура $\mathrm{i}$ методологія індексу проводиться Об'єднаним дослідницьким центром Європейської комісії.

Індекс вимірює досягнення країни з точки зору стійкості суспільного розвитку за шкалою від 0 (найменший ступінь стійкості) до 10 (найвищий ступінь стійкості) на основі 21 показника (індикатора) в трьох вищевказаних базових категоріях [18].

Ще однією універсальною особливістю індексу є те, що він застосовується не тільки щодо суспільств (держав), але й до регіонів світу та всієї глобальної системи. Розглянемо далі «Індекс сталості суспільства» від глобального до національних рівнів.

Станом на 2016 р. найкращий показник сталості представлено в категорії «добробут людини», він складає 6,4 бали з 10 можливих. Екологічний та економічний добробут мають дещо гірші показники - 4,8 і 4,6 бали відповідно.

Щодо сталого розвитку регіонів світу, то в певних категоріях ситуація може здатися дещо неочікуваною. Так, наприклад, станом на 2016 р. у категорії економічного добробуту перші три позиції займають регіони Східної Африки, Західної Африки та Центральної Африки. Такі показники можна схарактеризувати загальним рівнем 
економічного зростання протягом поточного року на фоні решти регіонів світу. Як зазначається в доповіді за 2016 р., найменш сприятливими для економічного зростання $\epsilon$ країни з високим рівнем людського добробуту, оскільки показники економічного росту в них досягли високого рівня і на фоні інших регіонів зростання з кожним роком $\epsilon$ все повільнішим [28]. Щодо динаміки економічного зростання протягом 2006-2016 рр., то ситуація є кардинально протилежною - перші позиції тут займають регіони Південної Європи, Північної Європи та Західної Європи. Такі показники можна схарактеризувати значним економічним зростанням протягом 10-річного періоду [24; $25 ; 26 ; 27 ; 28]$.

Топ регіонів добробуту людини за 2016 р. виглядає наступним чином: Західна Європа, Північна Європа, Південна Європа. Розподілення регіонів у першій трійці залежить від рівня нинішнього економічного добробуту і не залежить від економічного росту протягом останнього року на фоні інших регіонів [28]. Динаміка зростання добробуту людини в період з 2006 по 2016 рр. має дещо інший вигляд: Південна Азія, Південно-Східна Азія, Східна Африка. Ці регіони мають перші місця в рейтингу завдяки найшвидшій динаміці зростання даного показника на фоні інших регіонів світу, хоча $\mathrm{i}$ мають не дуже високі показники станом на 2016 р. [24; 25; 26; 27; 28].

У першій трійці за рівнем екологічному добробуту станом на 2016 р. перебувають регіони Океанії (включно з Австралією та Новою Зеландією), Центральної Америки, Західної Свропи. Саме в цих регіонах зростання екологічного добробупуротягом року було найбільш помітним [28]. Щодо першої трійки протягом десятирічного періоду (2006-2016 рр.), то ситуація є наступною: Західна Африка, Південно-Східна Азія, Центральна Азія.

Перейшовши від глобального до регіонально та від регіонального до національних індексів сталості суспільства, наведемо наступний рейтинг першої п'ятірки держав за трьома основними категоріями «Індексу сталості суспільства»з 2006 по 2016 рр. (див. табл. 2) $[24 ; 25 ; 26 ; 27 ; 28]$.

Національний рейтинг сталості суспільства (2006-2012рр.)

Табличя 2

\begin{tabular}{|l|c|c|c|c|c|c|}
\hline \multirow{2}{*}{ Держава } & 2006 & 2008 & 2010 & 2012 & 2014 & 2016 \\
\cline { 2 - 8 } \multicolumn{1}{c|}{1} & \multicolumn{7}{c|}{ Рейтинг добробуту людини } \\
\hline Фінляндія & 2 & 3 & 4 & 5 & 6 & 7 \\
\hline Німеччина & 1 & 1 & 1 & 1 & 1 & 1 \\
\hline Нідерланди & 9 & 10 & 2 & 5 & 4 & 2 \\
\hline Ісландія & 7 & 5 & 5 & 6 & 3 & 3 \\
\hline Норвегія & 4 & 15 & 14 & 2 & 2 & 4 \\
\hline & 5 & 4 & 4 & 4 & 5 & 5 \\
\hline Бурунді & 30 & 24 & 12 & 3 & 1 & 1 \\
\hline Того & 15 & 5 & 2 & 44 & 23 & 2 \\
\hline Лесото & 1 & 4 & 4 & 2 & 3 & 3 \\
\hline ЦАР & 8 & 7 & 9 & 4 & 6 & 4 \\
\hline Уганда & 12 & 13 & 14 & 7 & 7 & 5 \\
\hline
\end{tabular}


ISSN 2078-144X. Вісник Львівського університету. Серія соціологічна. 2017. Випуск 11

Закінчення табл. 2

\begin{tabular}{|c|c|c|c|c|c|c|}
\hline 1 & 2 & 3 & 4 & 5 & 6 & 7 \\
\hline \multicolumn{7}{|c|}{ Рейтинг економічного добробуту } \\
\hline Норвегія & 6 & 4 & 2 & 1 & 1 & 1 \\
\hline Швейцарія & 1 & 1 & 1 & 2 & 2 & 2 \\
\hline Естонія & 10 & 3 & 5 & 13 & 5 & 3 \\
\hline Швеція & 3 & 6 & 3 & 4 & 3 & 4 \\
\hline Чехія & 11 & 9 & 6 & 8 & 7 & 5 \\
\hline
\end{tabular}

Для здійснення порівняльного дослідження проведемо крос-темпоральний аналіз «Індексу сталості суспільства» для України за трьома базовими категоріями за період з 2006 по 2016 рр. (див. рис. 1).

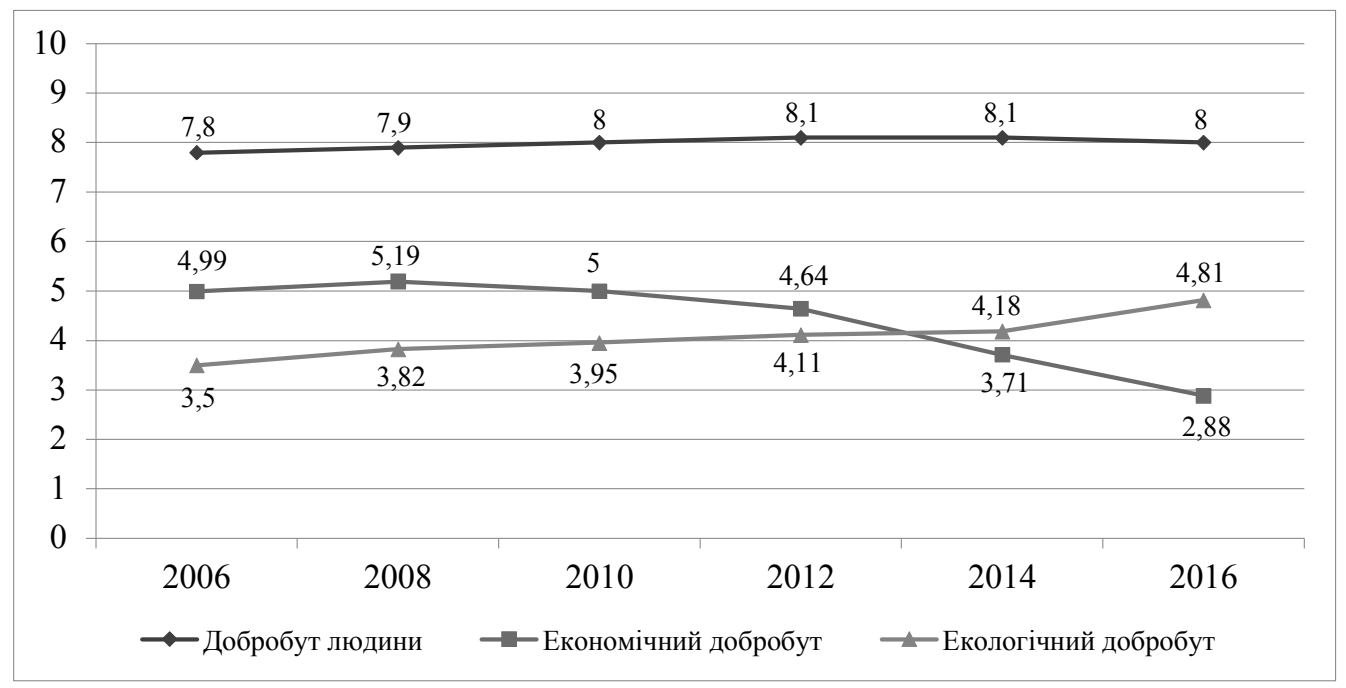

Рис. 1. Динаміка сталого розвитку України

Як можна побачити з графіка, Україна має найкращі показники сталого розвитку у категорії «добробут людини» (8 балів), протягом 2014-2016 рр. цей показник погіршився лише на 0,1 бала і характеризується як доволі високий.

Економічний добробут України станом на 2016 р. перебуває на дуже низькому рівні та має динаміку постійного спаду. Якщо в 2006 р. показник сталості економіки становив близько 5 балів, то починаючи з 2012 і по 2016 рр. він знизився більше ніж на 2 бали, що є дуже поганим результатом у порівнянні з іншими державами.

Найбільш сприятлива динаміка росту спостерігається в категорії екологічного добробуту, протягом 2006-2016 рр. цей показник покращився на 1,31 бала. Сама категорія екологічного добробуту має середні показники сталого розвитку [29].

Особливої уваги заслуговують субнаціональні (регіональні) вимірювання сталого розвитку в світі та в Україні зокрема. Автор використовує «Індекс сталого розвитку» 
(Sustainable Development Index) регіонів України, розроблений колективом науковців під керівництвом академіка НАН України М. З. Згуровського.

Індекс сталого розвитку регіонів України містить: 1) компоненту якості життя інтегровану оцінку, яка враховує сумісно усі три виміри сталого розвитку і тим самим відображає зв'язок між трьома нероздільними сферами розвитку суспільства: економічною, екологічною та соціальною; 2) компоненту безпеки життя - інтегровану оцінку, яка враховує сумарний вплив сукупності загроз на сталий розвиток регіонів [1, с. 10].

Наведемо рейтинг сталого розвитку регіонів України станом на 2013 р. (див. табл. 3)

Рейтинг сталого розвитку регіонів України (2013 р.)

Таблиия 3

\begin{tabular}{|l|c|c|c|c|c|}
\hline $\begin{array}{c}\text { Адміністративно- } \\
\text { територіальна } \\
\text { одиниця }\end{array}$ & $\begin{array}{c}\text { Рейтинг } \\
\text { сталого } \\
\text { розвитку }\end{array}$ & $\begin{array}{c}\text { Значення } \\
\text { індексу } \\
\text { сталого } \\
\text { розвитку }\end{array}$ & $\begin{array}{c}\text { Адміністративно- } \\
\text { територіальна одиниця }\end{array}$ & $\begin{array}{c}\text { Рейтинг } \\
\text { сталого } \\
\text { розвитку }\end{array}$ & $\begin{array}{c}\text { Значення } \\
\text { індексу } \\
\text { сталого } \\
\text { розвитку }\end{array}$ \\
\hline м. Київ & 1 & 1,3395 & Вінницька обл. & 15 & 0,9394 \\
\hline Чернівецька обл. & 2 & 1,0527 & Черкаська обл. & 16 & 0,9206 \\
\hline $\begin{array}{l}\text { Івано-Франківська } \\
\text { обл. }\end{array}$ & 3 & 1,0105 & Житомирська обл. & 17 & 0,9191 \\
\hline Закарпатська обл. & 4 & 1,0039 & Запорізька обл. & 18 & 0,8815 \\
\hline Тернопільська обл. & 5 & 1,0037 & АР Крим & 19 & 0,8732 \\
\hline Львівська обл. & 6 & 0,9919 & Сумська обл. & 20 & 0,8689 \\
\hline Київська обл. & 7 & 0,9888 & Одеська обл. & 21 & 0,8619 \\
\hline Полтавська обл. & 8 & 9,9795 & Донецька обл. & 22 & 0,8578 \\
\hline Хмельницька обл. & 9 & 0,9692 & Дніпропетровська обл. & 23 & 0,8549 \\
\hline Харківська обл. & 10 & 0,9673 & Херсонська обл. & 24 & 0,8516 \\
\hline Рівненська обл. & 11 & 0,9625 & Миколаївська обл. & 25 & 0,8424 \\
\hline м. Севастополь & 12 & 0,9527 & Луганська обл. & 26 & 0,8295 \\
\hline Чернігівська обл. & 13 & 0,9485 & Кіровоградська обл. & 27 & 0,8275 \\
\hline Волинська обл. & 14 & 0,9450 & & & \\
\hline
\end{tabular}

Усі 27 адміністративно-територіальних одиниць розділені на чотири кластери в залежності від рівня сталого розвитку. До групи з найвищим рівнем сталості належить м. Київ. Далі йде група з високим рівнем сталого розвитку, до якої входять Чернівецька, Івано-Франківська, Закарпатська, Тернопільська, Львівська, Київська та Полтавська області. До кластеру з середнім розвитком відносяться Хмельницька, Харківська, Рівненська, Чернігівська, Волинська, Вінницька, Черкаська, Житомирська області та м. Севастополь. I до групи з низьким рівнем сталого розвитку ввійшли Запорізька, Сумська, Одеська Донецька, Дніпропетровська, Херсонська, Миколаївська, Луганська, Кіровоградська області та АР Крим [1, с. 38-39].

Отже, індекси та індикатори сталого розвитку на сьогодні використовуються для вимірювання рівня сталого розвитку суспільства на глобальному, регіональному, національному та субнаціональному рівнях. Дослідження проводяться як міжнародними, так і національними організаціями та установами, що в свою чергу дозволяє виміряти сталий розвиток на різних рівнях. 
Висновки. Концептуального узагальнення дослідження, пов'язані зі сталим розвитком, набувають у другій половині XX ст., актуальність та науково-практичне значення підсилюється участю ООН у розробці цілей і завдань, необхідних для досягнення сталого розвитку глобального суспільства й окремих суспільств (держав) зокрема. Підвищення економічного, екологічного добробуту та добробуту людини $є$ основними завданнями $\mathrm{OOH}$, для вирішення яких потребується об'єднання всього світового суспільства. 3 метою вирішення проблем сталого розвитку в окремих державах формуються національні доктрини для досягнення сталості суспільства і вирішення проблем економічного, екологічного та соціального характеру.

Для досягнення сталого розвитку світової спільноти міжнародними науковими центрами та інститутами розробляються індекси сталого розвитку, або індекси, спрямовані на висвітлення окремих компонентів сталого розвитку. Це дає змогу продемонструвати ситуацію, що склалася в різних регіонах світу, та висвітлити динаміку змін за певний проміжок часу. Складання рейтингів держав світу за рівнем сталого розвитку дає можливість побачити проблемні сторони в тій чи іншій сфері людського життя та використати наявні ресурси для їх подолання.

У статті автор продемонстрував місце України за рівнем сталості суспільства на фоні інших держав, а також динаміку змін за останнє десятиліття, що має скоріше негативний, ніж позитивний характер, оскільки рівень людського добробуту є дуже низьким і з кожним роком погіршується. Підвищеннядобробуту людини можливе в першу чергу після підвищення економічного становища населення та зменшення розриву між багатими і бідними прошарками суспільства, про це свідчить практика європейських держав, зокрема Норвегії, Швеції, Фінляндії, Німеччини, Нідерландів, Швейцарії та інших. Саме в цих державах рівень економічного добробуту безпосередньо впливає на рівень добробуту людини, що характеризується високими позиціями в світових рейтингах відповідно.

Використання вимірювальної техніки для дослідження рівня та стану сталого розвитку є характерним для глобального, регіонального, національного та локального рівнів. У роботі наведено вимірювання сталого розвитку всієї світової спільноти за трьома базовими індикаторами (економічний, екологічний і соціальний), а також продемонстровано приклади вимірювання світових регіонівта окремих держав. Проте, як показує практика, національне вимірювання сталого розвитку - це не межа досліджень. Вимірювання сталого розвитку суспільств відбуваються і більш локалізовано, в Україні це адміністративно-територіальні одиниці вищого рівня.

Автор вважає, що методологію, взяту для вимірювання сталого розвитку регіонів світу та держав, можна адаптувати також для можливості дослідження сталого розвитку невеликих за територією та численністю населених пунктів, що в свою чергу характеризує глоболокальний вимір в концепції сталого розвитку.

\section{СПИСОК ВИКОРИСТАНОЇ ЛІТЕРАТУРИ}

1. Аналіз сталого розвитку: глобальний і регіональний контексти: монографія / Міжнар. рада з науки (ICSU) та ін.; наук. кер. проекту М. З. Згуровський. - К.: НТУУ «КПІ», 2014. - Ч. 2. Україна в індикаторах сталого розвитку (2013). - 172 с. 
2. Большаков Б. Е. Как измерить устойчивое развитие // Вестник РАЕН. - 2004. - № 6. C. $70-83$.

3. Большаков Б. Е., Рябкова С. А. Возникновение и основные проблемы вхождения понятия «устойчивое развитие» в мировую политику и науку // Приложение к учебнометодическому комплексу «Теория и методология проектирования устойчивого развития социо-природных систем». - Дубна, 2009. - Вып. 1. - 210 с.

4. Воззвание Тегеранской конференции. Принято 13 мая 1968 года Международной конференцией по правам человека в Тегеране [Электронный ресурс]. - Режим доступа: http://www.un.org/ru/documents/decl_conv/declarations/st_hr1_57.shtml

5. Декларация Конференции Организации Объединенных Наций по проблемах окружающей человека среды. Принята Конференцией Организации Объединенных Наций по проблемам окружающей человека среды, Стокгольм, 1972 год [Электронный pecypc]. - Режим доступа: http://www.un.org/ru/documents/decl_conv/declarations/declarathenv.shtml

6. Декларация по окружающей среде и развитию. Принята Конференцией ООН по окружающей среде и развитию, Рио-де-Жанейро, 3-14 июня 1992 года [Электронный pecypc]. - Режим доступа: http://www.un.org/ru/documents/decl_conv/declarations/pdf/ riodecl.pdf

7. Декларация тысячелетия Организации Объединенных наций. Принята резолюцией 55/2 Генеральной Ассамблеи от 8 сентября 2000 года [Электронный ресурс]. Режим доступа: https://documents-dds-ny.un.org/doc/UNDOC/GEN/N00/559/53/PDF/ N0055953.pdf?OpenElement

8. Йоханнесбургская встреча на высшем уровне. 26 августа - 4 сентября 2002 года, Йоханнесбург [Электронный ресурс]. - Режим доступа: http://www.un.org/ru/events/ pastevents/wssd.shtml

9. Йоханнесбургская декларация по устойчивому развитию. Принята на Всемирной встрече на высшем уровне по устойчивому развитию (Йоханнесбург, Южная Африка, 26 августа - 4 сентября 2002 года) [Электронный ресурс]. - Режим доступа: http:// www.un.org/ru/documents/decl_conv/declarations/pdf/decl_wssd.pdf

10. Моисеев Н. Н. Судьба цивилизации. Путь Разума. - М.: Я̆зыки рус. культуры, 2000. $224 \mathrm{c}$.

11. Наше общее будущее: Доклад Международной комиссии по окружающей среде и развитию (МКОСР): пер. с англ.; под ред. С. А. Евтеева и Р. А. Перелета. - Москва: Прогресс, 1989. - 372 с.

12. Оленьев В. В., Федотов А. П. Глобалистика на пороге XXI века // Вопросы философии. - 2003. - № 4. - С. 18-30.

13. Перелет P. A. Переход к эре устойчивого развития? // Россия в окружающем мире: 2003 (Аналитический ежегодник). - М.: Изд-во МНЭПУ, 2003. - 336 с.

14. План выполнения решений Всемирной встречи на высшем уровне по устойчивому развитию. Принят на 17-м пленарном заседании 4 сентября 2002 года [Электронный pecypc]. - Режим доступа: http://www.un.org/ru/events/pastevents/pdf/plan_wssd.pdf

15. Повестка дня на XXI век. Принята Конференцией ООН по окружающей среде и развитию, Рио-де-Жанейро, 3-14 июня 1992 года [Электронный ресурс]. - Режим доступа: http://www.un.org/ru/documents/decl_conv/conventions/pdf/agenda21.pdf

16. Развитие и международное экономическое сотрудничество: проблемы окружающей среды. Доклад Всемирной комиссии по вопросам окружающей среды и развития. A/42/427 от 4 августа 1987 года [Электронный ресурс]. - Режим доступа: http://www. un.org/ru/ga/pdf/brundtland.pdf

17. Резолюция, принятая Генеральной Ассамблеей 25 сентября 2015 года. Преобразование 
нашего мира: Повестка дня в области устойчивого развития на период до 2030 года [Электронный ресурс]. - Режим доступа: http://unctad.org/meetings/en/SessionalDocuments/ares70d1_ru.pdf

18. Рейтинг стран мира по уровню устойчивости общества [Электронный ресурс] // Информационно-аналитический портал «Гуманитарные Технологии». - Режим доступа: http://gtmarket.ru/ratings/sustainable-society-index/info

19. Садовенко А., Масловська Л., Середа В. Сталий розвиток суспільства: навчальний посібник / [упоряд. А. Садовенко, Л. Масловська, В. Середа]. - 2-е вид. - К., 2011. 392 c.

20. Сталий розвиток регіонів України / науковий керівник М. З. Згуровський. - К.: НТУУ «КПІ», 2009. - $197 \mathrm{c}$.

21. Урсул А. Д., Романович А. Л. На пути к устойчивому будущему // Устойчивое развитие. Наука и практика. - 2002. - № 1.

22. Index of Economic Freedom 2017 [Electronic source]. - Available at: http://www.heritage. org/index

23. Socioeconomic Data and Applications Center (SEDAC). Environment Sustainability Index (ESI) [Electronic source]. - Available at: http://sedac.ciesin.columbia.edu/data/collection/ esi

24. Sustainable Society Index 2008 [Electronic source]. - Available at: http://www.ssfi ndex. com/ssi2016/wp-content/uploads/pdf/ssi-2008.pdf

25. Sustainable Society Index 2010 [Electronic source]. - Available at: http://www.ssfi ndex. com/ssi2016/wp-content/uploads/pdf/Publication_SSI2010.pdf

26. Sustainable Society Index 2012 [Electronic source]. - Available at: http://www.ssfi ndex. com/ssi2016/wp-content/uploads/pdf/ssi2012.pdf

27. Sustainable Society Index 2014 [Electronic source]. - Available at: http://www.ssfi ndex. com/ssi2016/wp-content/uploads/pdf/SSI2014.pdf

28. Sustainable Society Index. Main results 2016 [Electronic source]. - Available at: http:// www.ssfi ndex.com/results/main-results-2016

29. Sustainable Society Index. Maps [Electronic source]. - Available at: http://www.ssfi ndex. com/ssi2016/maps2016/wellbeings2016/StatPlanet.html

30. The Economist Intelligence Unit. The Quality-of-Life Index [Electronic source]. - Available at: https://www.economist.com/media/pdf/QUALITY_OF_LIFE.pdf

31. The Global Competitiveness Index. The Global Competitiveness Report 2016-2017 [Electronic source]. - Available at: http://reports.weforum.org/global-competitiveness-index

32. United Nations Development Programme. Development Reports Human Development Index [Electronic source]. - Available at: http://hdr.undp.org/en/content/human-development-index-hdi

\section{REFERENCES}

1. Zgurovs'kyj, M. Z., ed. Analiz stalogo rozvytku: global'nyj i regional'nyj konteksty: monografi ja. Ch. 2. Ukrai'na v indykatorah stalogo rozvytku (2013) [Sustainable development analysis: global and regional contexts: Monograph. Part 2. Ukraine in indicators of sustainable development (2013)]. Kyiv: National Technical University of Ukraine «Kyiv Polytechnic Institute», 2014. [in Ukrainian].

2. Bol'shakov, B. E. «Kak izmerit' ustojchivoe razvitie» [«How to measure sustainable development»]. Bulletin of the Russian Academy of Natural Sciences 6 (2004): 70-83. [in Russian]. 
3. Bol'shakov, B. E. and Rjabkova S. A. Vozniknovenie i osnovnye problemy vhozhdenija ponjatija «ustojchivoe razvitie» v mirovuju politiku i nauku [The emergence and main problems of the introduction of the concept of «sustainable development» into world politics and science]. Dubna, 2009. [in Russian].

4. United Nations. «Final Act of the Tehran Conference on Human Rights, Tehran, 13 May 1968.» Accessed October 30, 2017. http://www.un.org/ru/documents/decl_conv/declarations/st_hr1_57.shtml [in Russian].

5. United Nations. «Declaration of the United Nations Conference on the Human Environment, June 1972.» Accessed October 30, 2017. http://www.un.org/ru/documents/decl_conv/ declarations/declarathenv.shtml [in Russian].

6. United Nations. «Rio Declaration on Environment and Development, Rio de Janeiro, 3-14 June 1992.» Accessed October 30, 2017. http://www.un.org/ru/documents/decl_conv/declarations/pdf/riodecl.pdf [in Russian].

7. United Nations. «55/2. United Nations Millennium Declaration. Resolution adopted by the General Assembly, 8 September 2000.» Accessed October 30, 2017. https://documents-ddsny.un.org/doc/UNDOC/GEN/N00/559/53/PDF/N0055953.pdf?OpenElement [in Russian].

8. World Summit on Sustainable Development, Johannesburg, August 26 - September 4, 2002. Accessed October 30, 2017. http://www.un.org/ru/events/pastevents/wssd.shtml [in Russian].

9. United Nations. «Johannesburg Declaration on Sustainable Development. World Summit on Sustainable Development, 4 September 2002.» Accessed October 30, 2017. http://www. un.org/ru/documents/decl_conv/declarations/pdf/decl_wssd.pdf [in Russian].

10. Moiseev, N. N. Sud'ba civilizacii. Put' Razuma [The fate of civilization. The way of mind]. Moscow: Languages of Russian culture, 2000. [in Russian].

11. Report of the World Commission on Environment and Development: «Our Common Future». Moscow: Progress, 1989. [in Russian].

12. Olen'ev, V. V. and Fedotov A. P. «Globalistika na poroge XXI veka» [ «Global studies on the threshold of the 21st century»]. Questions of philosophy 4 (2003): 18-30. [in Russian].

13. Perelet, R. A. Perehod k jere ustojchivogo razvitija? [Is it transition to the era of sustainable development?]. Russia in the World: 2003 (Analytical yearbook). Moscow, 2003.

14. Plan of Implementation of the World Summit on Sustainable Development, 17th Plenary Meeting (PM) and Round-up, 4 September 2002. Accessed October 30, 2017. http://www. un.org/ru/events/pastevents/pdf/plan_wssd.pdf [in Russian].

15. United Nations. «Agenda 21. United Nations Conference on Environment \& Development Rio de Janerio, Brazil, 3 to 14 June 1992.» Accessed October 30, 2017. http://www.un.org/ ru/documents/decl_conv/conventions/pdf/agenda21.pdf [in Russian].

16. Report of the World Commission on Environment and Development: «Development and international economic cooperation: environmental problems», A/42/427, 4 August 1987. Accessed October 30, 2017. http://www.un.org/ru/ga/pdf/brundtland.pdf [in Russian].

17. United Nations. «Transforming our world: the 2030 Agenda for Sustainable Development, 25 September 2015.» Accessed October 30, 2017. http://unctad.org/meetings/en/SessionalDocuments/ares70d1_ru.pdf [in Russian].

18. Information-analytical portal «Humanitarian Technologies» «Sustainable Society Index Ranking». Accessed October 30, 2017. http://gtmarket.ru/ratings/sustainable-society-index/ info [in Russian].

19. Sadovenko, A., Maslovs'ka, L., and Sereda V. Stalyj rozvytok suspil'stva: navchal'nyj posibnyk [Sustainable development of society: a manu training manual]. 2nd ed. Kyiv, 2011. [in Ukrainian].

20. Zgurovs 'kyj, M. Z., ed. Stalyj rozvytok regioniv Ukrai'ny [Sustainable development of re- 
gions of Ukraine]. Kyiv: National Technical University of Ukraine «Kyiv Polytechnic Institute», 2009. [in Ukrainian].

21. Ursul, A. D., and Romanovich A. L. «Na puti k ustojchivomu budushhemu» [«On the road to sustainable future»]. Sustainable development. Science and practice 1 (2002). [in Russian].

22. Index of Economic Freedom 2017. Accessed October 30, 2017. http://www.heritage.org/ index

23. Socioeconomic Data and Applications Center (SEDAC). Environment Sustainability Index (ESI). Accessed October 30, 2017. http://sedac.ciesin.columbia.edu/data/collection/esi

24. Sustainable Society Index 2008. Accessed October 30, 2017. http:/www.ssfi ndex.com/ ssi2016/wp-content/uploads/pdf/ssi-2008.pdf

25. Sustainable Society Index 2010. Accessed October 30, 2017. http://www.ssfi ndex.com/ ssi2016/wp-content/uploads/pdf/Publication_SSI2010.pdf

26. Sustainable Society Index 2012. Accessed October 30, 2017. http://www.ssfi ndex.com/ ssi2016/wp-content/uploads/pdf/ssi2012.pdf

27. Sustainable Society Index 2014. Accessed October 30, 2017. http://www.ssfi ndex.com/ ssi2016/wp-content/uploads/pdf/SSI2014.pdf

28. Sustainable Society Index. Main results 2016. Accessed October 30, 2017. http://www. ssfi ndex.com/results/main-results-2016

29. Sustainable Society Index. Maps. Accessed October 30, 2017. http://www.ssfi ndex.com/ ssi2016/maps2016/wellbeings2016/StatPlanet.html

30. The Economist Intelligence Unit. The Quality-of-Life Index. Accessed October 30, 2017. https://www.economist.com/media/pdf/QUALITY_OF_LIFE.pdf

31. The Global Competitiveness Index. «The Global Competitiveness Report 2016-2017.» Accessed October 30, 2017. http://reports.weforum.org/global-competitiveness-index

32. United Nations Development Programme. «Development Reports Human Development Index.» Accessed October 30, 2017. http://hdr.undp.org/en/content/human-developmentindex-hdi

\title{
GLOBAL-LOCAL DIMENSION IN THE CONCEPT OF SUSTAINABLE DEVELOPMENT
}

\author{
O. G. Kononchuk \\ Rivne State University of Humanities, Plastova \\ Str., of. 229, Rivne, 33028, \\ Alexander.Kononchuk.USA@gmail.com
}

\begin{abstract}
The article deals with the global-local dimension in the concept of sustainable development of society and gives a comparative analysis of sustainable development of the regions of the world and individual states, and cross-temporal comparison from the global to the local levels is carried out. The author gives a chronological sequence of formation of the concept of sustainable development of society, in which the United Nations and a number of resolutions and declarations adopted by the General Assembly since the second half of the 20th century played a major role. The article presents evolution of the concept of sustainable
\end{abstract}


development from purely environmental and economic interpretations to the interpretation of sustainable development as an integrated system that encompasses environmental, economic and social indicators. Also, the article presents interpretations of the category of sustainable development from both foreign and domestic scientists.

The author focuses on indices and indicators of sustainable development of society that makes it possible to measure the level of sustainability of society (societies) from global to local levels. For the global-local measurement of sustainable development, the author uses two indices: the Sustainable Society Index and the Sustainable Development Index of the regions of Ukraine. First index measures the sustainability of society at global, regional (by regions of the world) and national levels, the ranking of countries and regions of the world, as well as the dynamics of changes in sustainability of society at different levels during ten-year period are presented. The second index is used to study sustainable development of the regions of Ukraine.

The article compares the level of sustainability of Ukrainian society and other countries of the world, and also shows the dynamics of changes over the last decade, which is more negative than positive, because the level of human welfare is very low and reduces year after year. The improvement of human well-being is possible, fi rst of all, after increasing the economic situation of the population and reducing the gap between rich and poor strata of society, as evidenced by practice of European states, in particular Norway, Sweden, Finland, Germany, Netherlands, Switzerland and others. In these states the level of economic welfare directly affects the level of human well-being that is characterized by high positions in world rankings.

Measuring techniques for studying the level and state of sustainable development are applied to global, regional, national and local levels. The article presents measurement of sustainable development of the entire world community in terms of three basic indicators (economic, environmental and social), as well as examples of measurement of world regions and individual states. Measurements of sustainable development of societies can be more localized, in Ukraine these are the administrative-territorial units of the highest level.

Key words: sustainable development, concept of sustainable development, United Nations (UN), sustainable development indicator, sustainable development index, The Sustainable Society Index, The Sustainable Development Index. 